\title{
Ekonomik Büyüme ve
}

\section{Sağlık Harcamaları Arasındaki İlişki: MINT Ülkelerinden Ampirik Kanıtlar}

\section{The Relationship between Economic Growth and Health Expenditures: Empirical Evidence from MINT Countries}

\author{
Gülller Şahin $1^{*}$ (D), Eda Yalçınkaya ${ }^{2}$ \\ ${ }^{1}$ Bağımsız Araştırmacı, Kütahya, Türkiye \\ ${ }^{2}$ Bağımsız Araştırmacı, Tokat, Türkiye
}

$\ddot{O} \mathbf{z}$

Ekonomik büyümenin sağlık koşullarını iyileştirip iyileştirmediği, dolayısıyla sağlık kanalıyla toplumsal refahı destekleyip desteklemediği tartışmaları devam etmektedir. Bazı araştırmacılar ekonomik büyümenin sağlı çıktılarını iyileştirdiğini, bazıları ise büyümenin faydalarının abartıldığını iddia etmektedir. Devam eden bu tartışmalar, sağlık ekonomisi literatüründe büyüme ve sağlık konusunda araştırmaların yapılmasını gerekli kılmaktadır. Bu araştırmanın amacı, 2000-2016 zaman aralığı içerisinde ekonomik büyüme ve sağlık harcamaları arasındaki ilişkiyi Meksika, Endonezya, Nijerya ve Türkiye ülkeleri örneklem kümesi kapsamında incelemektir. Amaç kapsamında, sağlık harcamaları, gayri safi yurtiçi hâsıla, kamu sağlık harcamaları, yaşam beklentisi, nüfus, yaşlı ve genç bağımlılık oranı değişkenleri arasındaki ilişkilerin tahmin işlemlerinde panel veri analizi metodolojisi izlenmiştir. Sabit katsayılar modeline ait sonuçlarda, gayri safi yurtiçi hâsılanın ve kamu harcamalarının sağlık harcamalarını artırdı̆̆ı, genç ve yaşlı bağımlılık oranlarının ise azalttığı görülmüştür. Sonuçlara göre, gayri safi yurtiçi hâsıla ve kamu harcamaları \%1 arttığında, sağlık harcamaları sırasıyla yaklaşık olarak $\% 1.15$ ve $\% 0.57$ artmakta; genç ve yaşlı bağımlılık oranları $\% 1$ arttığında ise, sağlık harcamaları sırasıyla yaklaşık olarak \%4.79 ve \%3.65 azalmaktadır.

Anahtar Kelimeler: Ekonomik Büyüme, Sağlık Harcamaları, MINT Ülkeleri, Panel Veri Analizi.

\begin{abstract}
There is controversy as to whether economic growth improves health conditions and, therefore, supports social welfare through health. Some researchers argue that economic growth improves health outcomes, while others claim that the benefits of growth are exaggerated. These ongoing discussions necessitate research on growth and health in the health economics literature. The goal of this research is in the range of 20002016 when the relationship between economic growth and health expenditure Mexico, Indonesia, Nigeria and Turkey is to examine the scope of countries in the sample set. Within the scope of the aim, panel data analysis was performed for estimating the possible relationships between variables of health expenditures, gross domestic product, public health expenditures, life expectancy, population, old and young dependency rates. In the results of the fixed coefficients model, gross domestic product and public expenditures increased health expenditures and young and old dependency rates decreased health expenditures According to the results, when gross domestic product and public expenditures increased by $1 \%$ health expenditures increased by approximately $1.15 \%$ and $0.57 \%$, respectively; when young and old dependency rates increased by $1 \%$ health expenditures decreased by approximately $4.79 \%$ and $3.65 \%$ respectively.
\end{abstract}

Keywords: Economic Growth, Health Expenditures, MINT Countries, Panel Data Analysis. 


\section{Giriş}

Dünya Sağlık Örgütü (2019) tarafindan yapılan sağlık tanımı, “yalnızca hastalığın veya sakatlığın olmaması durumu değil, aynı zamanda tam bir fiziksel, zihinsel ve sosyal iyilik durumudur" şeklindedir. Belirtilen bu tam iyilik durumu, ülkelerin ekonomik büyüme amaçlarının hedeflerini ve sonuçlarını döngüsel bir çerçevede yansıtan parametrelerden biri olarak değerlendirilmektedir. Dolayısıyla sağlık parametreleri, ekonomik büyüme sürecindeki önemli araçlardan biri olarak görülmektedir. Özellikle gelişmiş ülkelerde, sağlık harcamalarının koruyucu hizmetlere; gelişmekte olan ülkelerde ise, tıbbi malzemelere ve ayakta bakım hizmetlerine finanse edilmesi refahın oluşmasında büyük önem arz etmektedir.

Dünya Bankası’nın 2019 yılı istatistiki verileri, 20. yüzyıl boyunca ülkelerin sağlık konusunda önemli kazanımlar sağladığını göstermektedir. Ülkelerin gelir gruplarına göre dağılımlarına bakıldığında, düşük gelirli ülkelerde 1960 yılında 39 yıl olan ortalama yaşam beklentisi, 2000 yılında 54 yıla, 2017 yılında ise 63 yıla çıkmıştır. Orta gelir grubundaki ülkelerde 1960 yılında 48 yıl olan ortalama yaşam beklentisi, 2000 yılında 67 y1l, 2017 yılında ise 72 y1l olarak gerçekleşmiştir. Yüksek gelir grubuna sahip ülkelerdeki ortalama yaşam beklentisi süreleri ise 1960, 2000 ve 2017 yıllarında sırasıyla 69, 78 ve 81 yıllarına yükselmiştir (Dünya Bankası, 2019). Sağlıklı beslenme, iyileştirilmiş hijyen koşulları, tıbbi teknolojilerdeki yenilikler, halk sağlığı altyapısı, daha iyi barınma şartları, sağlık hizmetleri için ödeme yapma kabiliyetinin artması, aşı ve ilaçların bulunması, temiz suya erişim gibi faktörler insanların ortalama yaşam beklentisi sürelerini aşamalı olarak artırmıştır. Söz konusu bu faktörlerin ortalama yaşam beklentisi süresine göreceli katkısı ise, ülkelerin ekonomik gelişme düzeylerine bağlı olarak değişmektedir (Bhargava, Jamison, Lau ve Murray, 2001, s. 5; Cutler, Deaton ve Lleras-Muney, 2006, s. 10).

Araştırmanın amacı doğrultusunda araştırma dört başlık altında örüntülenmiştir. Girişin ardılı, birinci başlıkta ekonomik büyüme ile sağlık arasındaki ilişkiye değinilmiş, ikinci başlıkta analizin örneklem kümesini oluşturan ülkelerin ekonomik büyüme ve sağlik parametreleri hakkında bilgi verilmiş, sonrasında ise ampirik literatür seçkisi ele alınmıştır. Araştırmanın dördüncü başlığında, ampirik analize ait örneklem grubu ve veri setine, metodolojiye ve bulgulara yer verilmiştir. Araştırma, sonuç ve tartışma kısmı ile tamamlanmıştır.

\section{Ekonomik Büyüme ile Sağlık Arasındaki İlişki}

Ekonomik büyüme ile sağlık parametrelerinin birbirine bağlı olduğu ve her iki unsurun da yoksulluğu etkilediği kuramsal olarak kabul edilmektedir. Kuramın temeli, "daha iyi sağlık koşullarının, daha yüksek oranlarda büyüme sonuçlarına yol açacağı” düşüncesidir. Çünkü, gelişmemiş ve gelişmekte olan ülke insanlarının, gelişmiş ülke insanlarına göre daha az sağliklı olduğu konusunda geniş bir konsensüs bulunmaktadır.

Büyüme ve sağlık ilişkisinin varlığına ilişkin iki makul açıklama vardır. Birinci açıklama, artan gelirin daha iyi sağlık koşullarına neden olduğu; ikinci açıklama ise, sağlıklı çalışanların daha üretken ve verimli oldukları, dolayısıyla daha yüksek gelir elde ettikleridir (Pritchett ve Summers, 1996, s. 844).

Sağlık koşullarının iyileştirilmesi, ekonomik büyümenin temel hedeflerinin bir sonucudur. Örneğin, uzun süreli yaşam beklentisinin tasarruf, sermaye birikimi ve yatırım oranlarını artırarak, daha yüksek büyüme oranlarına neden olduğu varsayılmaktadır (Rad, Vahedi, Teimourizad, Esmaeilzadeh, Hadian ve Pour, 2013, s. 163; Bloom, Canning ve Sevilla, 2001, s. 20). Sağlık çıktılarından önemli bir gösterge olan bebek, genç ve yaşlı ölüm oranlarının da fakir ülkelerde zengin ülkelerden çok daha yüksek olduğudur. İstatistiki kanıtlara bütüncül bir şekilde bakıldığında, ölümlerin azaltılmasının üç aşamayı kapsadığı görülmektedir. 18. yüzyılın ortasından 19. yüzyılın ortasına kadar olan ilk evre, gelişmiş beslenme koşulları ile ekonomik büyümenin sağlıkta büyük bir rol oynadığı aşamadır. 19. Yüzyılın son yıllarında ve 20. yüzyılda şehirlerdeki yüksek ölüm oranlarına bağlı olarak halk sağlığının önem kazandığı ikinci aşamada, temiz su temini, atıkların giderilmesi ve kişisel sağlık uygulamaları ağırlık kazanmıştır. 1930'lardan itibaren görülen üçüncü aşama ise, aşı ve antibiyotiklerle başlayan ve günümüzde sağlı sistemindeki teknolojilerle karakterize edilen pahalı ve yoğun 
kişisel müdahalelere doğru ilerleyen büyük tıp dönemi olmuştur (Cutler vd., 2006, s. 16). Geliri daha yüksek olan insanların daha uzun yaşadığı ülkelerde, ayrıca gelir ve ölüm oranları arasında da güçlü ilişkilerin varlığına rastlanmaktadır.

Sağlık koşullarındaki gelişmeler, yalnızca emeğin üretkenliği ile değil aynı zamanda sermaye birikimi yoluyla da çıktıyı artırmaktadır. Bu gelişmeler aynı zamanda yoksulluğun azaltılması ile ilgili diğer ekonomik büyüme hedeflerine ulaşmak için de bir araçtır. Sağlık koşullarındaki olumlu gelişmeler, yoksulluğun azaltılarak uzun vadede yüksek oranlarda ekonomik büyümeye katkı sağlamaktadır. Örneğin, gelişmemiş ve azgelişmiş ülkelerde toplam harcamalar içindeki sağlık harcamalarının yükü, ekonomik büyümenin önünde belirgin bir engel teşkil etmektedir. Sağlık harcamaları için daralan bütçe desteği ise, sağl1k hizmetlerinde verimsizliğe ve hizmetlerin düşük kalitede olmasına yol açmaktadır (Malik, 2011, s. 4-5; Bloom vd., 2001, s. 21).

Tarihsel deneyimlere bakıldığında ülkelerin sağlık harcamalarında büyük bir değişim yaşandığı görülmektedir. 2000 yılında yüksek gelirli ülkelerde yaklaşık 2.430 \$, düşük gelirli ülkelerde yaklaşık 15 \$ olan kişi başına sağlık harcamaları, 2016 yılında yüksek gelirli ülkelerde yaklaşı 5.180 \$'a düşük gelirli ülkelerde ise yaklaşı 33 \$'a yükselmiştir. Aynı zamanda gelişmiş ülkelerde gayri safi yurtiçi hâsılanın (GSYH) yaklaşık \%12'sinden fazlasının sağlık harcamalarına ayrılması, gelişmekte olan ülkelerde ise bu oranın \%6'dan az olması GSYH içindeki sağlık harcamalarının payının ülkelerin gelişmişlik düzeylerine göre değişkenlik gösterdiği görüşünü desteklemektedir (Rezaei, Fallah, Karyani, Daroudi, Zandiyan ve Hajizadeh, 2016, s. 2; Dünya Bankas1, 2019).

Gelişimsel süreç içerisinde ülkelerde medikal ve sağlik hizmetlerine duyulan ihtiyacın sürekli olarak arttığı, bu durumun ise geleneksel sağlık endüstrisi üzerinde büyük bir baskı oluşturduğu bilinmektedir. Gelişmiş ülkelerde, devletin vatandaşlara yönelik sağlık hizmetleri ile ilgili mali harcamalarının giderek arttığı görülmektedir. Gelişmekte olan ülkelerdeki temel sorun ise, tıbbi kaynakların ülkenin gelişmiş ve geri kalmış bölgeleri arasındaki eşit olmayan dağılımıdır. Avustralya, Amerika Birleşik Devletleri (ABD), İngiltere, Çin gibi dünyadaki gelişmiş çoğu ülke yaşlanan nüfus sorunuyla karşı karşıyadır. Yaşlanma ile ilgili çeşitli kronik hastalıkların görülme sıklığı da giderek artış göstermektedir. Dolayısıyla, yaşam beklentisi süresinin uzunluğu sağlık harcamalarına yapılan yatırımları ve araştırma-geliştirme maliyetlerini artırmaktadır (Zhao, Li ve Zhang, 2019, s. 68).

Ekonomik büyüme ile sağlık arasındaki ilişkiye yönelik oluşan bir diğer geniş konsensüs ise, gelişmiş ülkelerde yaşayan insanların, sağlık hizmetlerinin kullanımında ve yararları hakkında daha fazla bilgiye sahip olmaları, aynı zamanda kişisel sağlık bakımına gelişmemiş ülkelerde yaşayan insanlardan daha fazla önem göstermeleridir (Samadi ve Rad, 2013, s. 64).

Sağlık hizmetleri, verimliliği ya da üretkenliği doğrudan ve dolaylı olmak üzere başlıca iki kanaldan etkilemektedir. Sağlığın verimlilik üzerindeki doğrudan etkisi, çoğu araştırmanın kuramsal ve ampirik kanıtları tarafından doğrulanan sağlıklı insanların daha verimli çalışanlar olduğu bilgisidir. Sağlığın verimlilik üzerindeki dolaylı etkisi ise eğitim aracıllı̆ı ile gerçekleşmektedir. Bu durumda sağlı koşullarının iyileştirilmesi okullaşma oranlarını artırmaktadır. Aynı zamanda, sağlıkı̈ öğrencilerin devamsızlık oranlarının daha düşük, bilişsel işlevselliklerinin ise daha yüksek olması sonucunda eğitimde kalite artmaktadır. Ayrıca, yaşam süresinin artması insanların emeklilik için tasarruf etmesine yol açabilmekte, dolayısıyla iş gücü başına düşen yatırımların ve fiziki sermayenin seviyesi yükselebilmektedir (Malik, 2011, s. 4).

1965-1990 yılları arasındaki verilerin analizi, yaşam beklentisi süresindeki iyileşmenin toplam büyümenin yaklaşık \%8'ini etkilediğini ifade etmektedir. Bu çalışmalara göre, büyüme etkisini sağlayan üç geniş mekanizma (Malik, 2011, s. 5):

- Sağlıklı iş gücü ve daha az devamsızlık nedeniyle verimlilikte görülen iyileşmeler,

- Yaşam süresi arttıkça beşeri ve fiziksel sermayeye yatırım yapmak için teşviklerin artması, 
- Çalışanların emekliliğe yönelik tasarruf yapmaları nedeniyle tasarruf oranlarındaki artış olarak ifade edilmektedir.

Yukarıda anlatılan bilgiler ışığında, iyileştirilmiş sağlık koşullarının refah üzerindeki etkisini açıklayan mekanizma Şekil 1 içerisindedir.

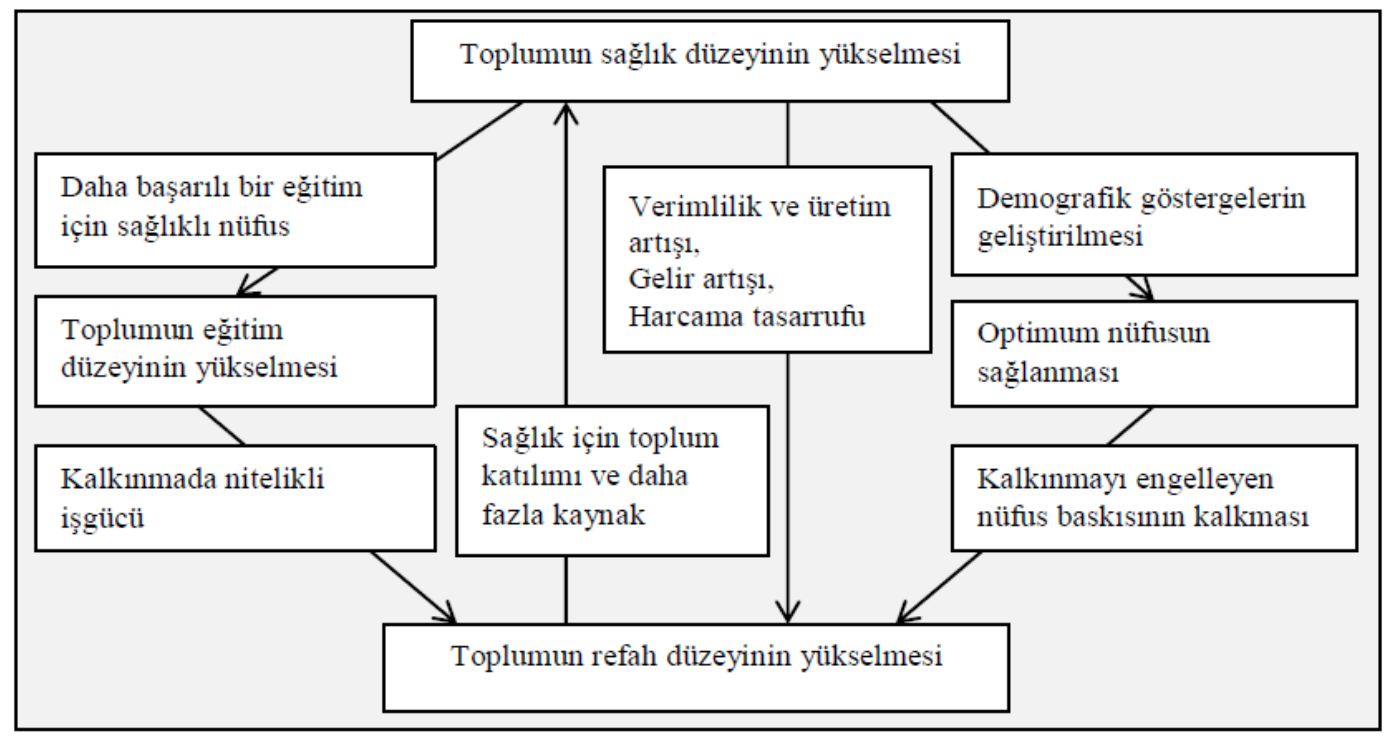

Şekil 1. Toplumsal refah ve sağlık arasındaki ilişki. "Türkiye'de Sağlık ve Ekonomik Büyüme Arasındaki Nedensellik İlişkisi”, S. Taban, 2006, Sosyoekonomi, 4(4), s. 34 makalesinden yeniden düzenlenerek alınmıştır. Telif Hakkı Sosyoekonomi Dergisine aittir, 2006.

Şekil 1 incelendiğinde; toplumsal refah ve sağlık arasındaki ilişkinin, toplumun sağlık düzeyinin yükselmesinden refah artışına ve refahtaki artıştan sağlık düzeyinin yükselmesine doğru geri bildirim etkisini yansıttığı görülmektedir.

\section{MINT Ülkelerinde Ekonomik Büyüme ve Sağlık Parametreleri}

Dünya ekonomisinin yeni ekonomi devleri olarak adlandırılan ve "Yeni Dörtlü" şeklinde ifade edilen MINT ülkeleri Meksika, Endonezya, Nijerya ve Türkiye’yi kapsamaktadır (Aydın ve Bashimov, 2018, s. 263). Söz konusu ülkelerin, özellikle dinamik nüfus yapılarına, stratejik konumlarına ve gelişmeye açık ekonomilerine bağlı olarak önümüzdeki yıllar içerisinde geleceğin yükselen ekonomileri arasında olacağı öngörülmektedir. Bu bağlamda araştırma MINT ülkeleri örneklem kümesi kapsamında gerçekleştirilmiştir.

Uluslararası Para Fonu (International Monetary Fund; IMF) tarafindan yayımlanan Dünya Ekonomik Görünümü Raporu'na göre, 2018 yılında GSYH büyüklügü bazında dünyanın en gelişmiş ekonomileri sıralamasındaki ilk 20 ülke arasında Meksika, Endonezya ve Türkiye bulunmaktadır. Meksika 1.223 milyar \$ GSYH büyüklüğü ile 15. sırada yer alırken, Endonezya 1.022 milyar \$ ile 16. sirada, Türkiye ise 766 milyar \$ ile 18. sıradadır. Nijerya, 2018 yılında 397 milyar \$ GSYH büyüklüğüne sahiptir (IMF, 2019).

Şekil 2 ele alındığında, GSYH büyüklüğü sıralamasına göre Meksika, Endonezya, Nijerya ve Türkiye'de yatırım ve tasarruf oranlarının gelirle aynı doğrultuda olması beklenirken bu sıralamanın değiştiği görülmektedir. 1990-2018 döneminde 2010 y1lı itibariyle ülkelerin yatırım ve tasarruf eğrileri aynı ülkelerin sıralamasını göstermektedir. Buna göre yüksekten düşüğe doğru bir sıralama Endonezya, Türkiye, Meksika ve Nijerya ülkelerine işaret etmektedir. 


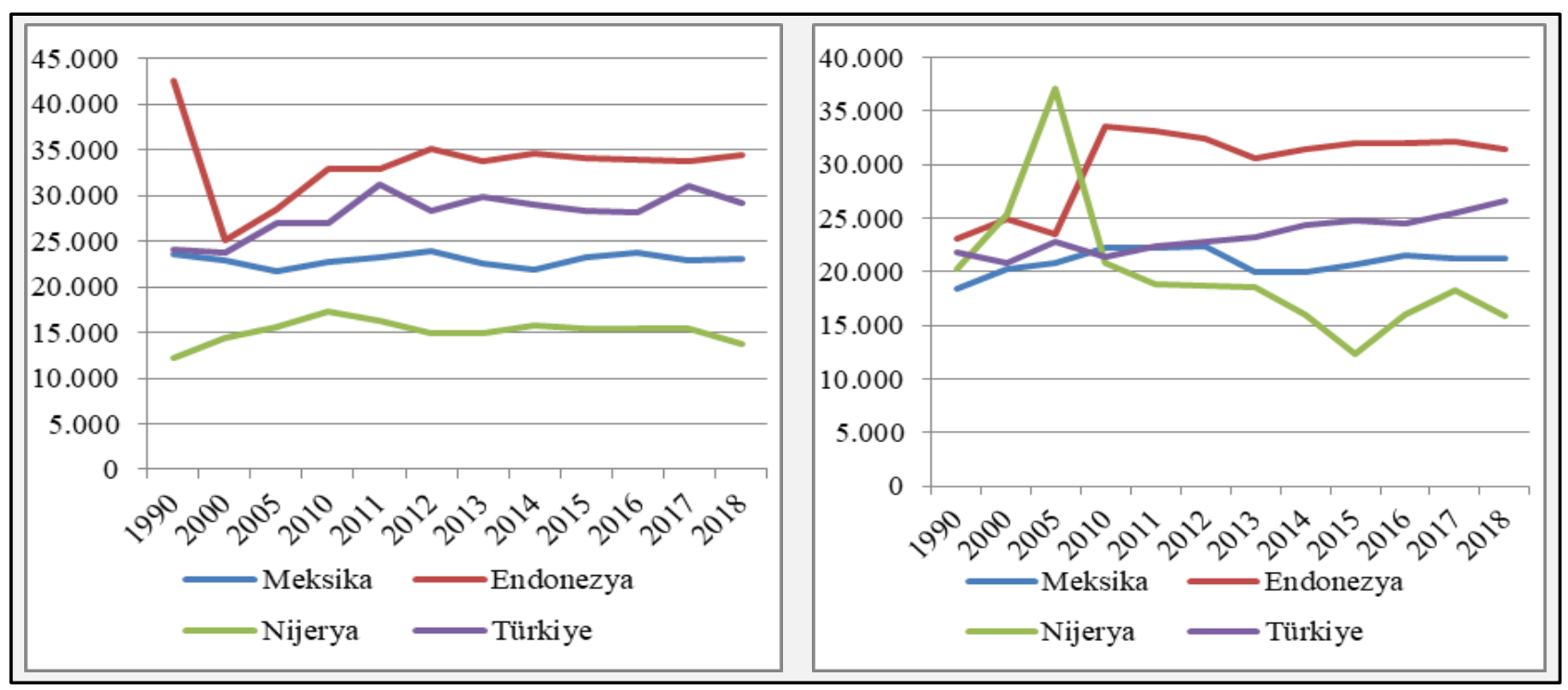

Şekil 2. IMF (2019) verilerine göre MINT ülkelerinde yatırım ve tasarruflar (milyar\$): 1990-2018

Tablo 1 içerisinde yer alan verilere göre, 2000-2016 zaman aralığında kamu sağlık harcamalarındaki yüksekten düşüğe doğru sıralamanın Türkiye, Meksika, Endonezya ve Nijerya; yıllık GSYH büyümesinin ise Nijerya, Endonezya, Türkiye ve Meksika şeklinde olduğu görülmektedir. Bu durum, dünyanın gelişmiş ekonomileri sıralamasında daha yüksek GSYH büyüklüğüne sahip olan Meksika ve Endonezya'nın, sağlık harcamalarına Türkiye'den daha az bütçe ayırdığına işaret etmektedir.

Tablo 1.

Kamu sağllk harcamaları ve GSYH: 2000-2016

\begin{tabular}{ccccccccc}
\hline \multirow{2}{*}{ Y1llar } & \multicolumn{2}{c}{ Kamu sağlik harcamaları (GSYH’nin \%si) } & \multicolumn{5}{c}{ GSYH büyümesi (yıllık, \%) } \\
& Meksika & Endonezya & Nijerya & Türkiye & Meksika & Endonezya & Nijerya & Türkiye \\
\hline 2000 & 2.012 & 0.577 & 0.531 & 2.850 & 4.942 & 4.920 & 5.016 & 6.640 \\
2001 & 2.109 & 0.779 & 0.525 & 3.312 & -0.404 & 3.643 & 5.918 & -5.962 \\
2002 & 2.165 & 0.677 & 0.331 & 3.569 & -0.040 & 4.499 & 15.329 & 6.430 \\
2003 & 2.402 & 0.818 & 0.590 & 3.602 & 1.446 & 4.780 & 7.347 & 5.608 \\
2004 & 2.575 & 0.749 & 0.820 & 3.556 & 3.921 & 5.031 & 9.251 & 9.644 \\
2005 & 2.454 & 0.732 & 0.682 & 3.348 & 2.308 & 5.693 & 6.439 & 9.010 \\
2006 & 2.412 & 0.831 & 0.714 & 3.572 & 4.495 & 5.501 & 6.059 & 7.110 \\
2007 & 2.517 & 1.019 & 0.854 & 3.632 & 2.291 & 6.345 & 6.591 & 5.030 \\
2008 & 2.607 & 0.898 & 0.832 & 3.823 & 1.144 & 6.014 & 6.764 & 0.845 \\
2009 & 2.850 & 0.922 & 0.650 & 4.455 & -5.286 & 4.629 & 8.037 & -4.704 \\
2010 & 2.896 & 0.761 & 0.448 & 3.942 & 5.118 & 6.224 & 8.006 & 8.487 \\
2011 & 2.916 & 0.800 & 0.479 & 3.709 & 3.663 & 6.170 & 5.308 & 11.113 \\
2012 & 3.003 & 0.872 & 0.544 & 3.545 & 3.642 & 6.030 & 4.230 & 4.790 \\
2013 & 3.124 & 0.926 & 0.489 & 3.451 & 1.354 & 5.557 & 6.671 & 8.491 \\
2014 & 2.895 & 1.076 & 0.446 & 3.374 & 2.804 & 5.007 & 6.310 & 5.167 \\
2015 & 2.993 & 1.213 & 0.589 & 3.234 & 3.288 & 4.876 & 2.653 & 6.086 \\
2016 & 2.852 & 1.398 & 0.475 & 3.384 & 2.922 & 5.033 & -1.617 & 3.184 \\
\hline
\end{tabular}

Not: Dünya Bankası Online Veri Tabanı’ndan doğrudan alınmıştır, 2019. 
Tablo 2 dikkate alındığında, 1960 yılına göre 2017 yılında yaşam beklentisi Meksika'da 1.35, Endonezya'da 1.43, Nijerya'da 1.48, Türkiye'de ise 1.68 kat artış göstermiştir. 2017 y1lı itibariyle en yüksek ortalama yaşam beklentisi süresine sahip ülkeler sırasıyla, Meksika, Türkiye, Endonezya ve Nijerya'dır. Aynı yıl içerisinde yaş bağımlılık oranları en düşük Endonezya'da, en yüksek ise Nijerya'da görülmektedir. Bağımlılık oranlarının 22 yıllık süreç içerisindeki ortalaması da 2017 yılı ile aynı sıralamayı takip etmektedir.

Tablo 2.

Yaş bağımlılık oranı ve ortalama yaşam beklentisi: 1960-2017

\begin{tabular}{ccccccccc}
\hline \multirow{2}{*}{ Yıllar } & \multicolumn{2}{c}{ Yaş bağımlılık oranı (çalışma yaşı nüfusunun \%si) } & \multicolumn{3}{c}{ Ortalama yaşam beklentisi (toplam, yıl) } \\
& Meksika & Endonezya & Nijerya & Türkiye & Meksika & Endonezya & Nijerya & Türkiye \\
\hline 1960 & 97.21 & 76.85 & 79.96 & 82.12 & 57.08 & 48.65 & 36.98 & 45.37 \\
1970 & 101.01 & 87.05 & 83.30 & 83.52 & 61.37 & 54.54 & 40.97 & 52.29 \\
1980 & 96.46 & 80.72 & 88.10 & 79.73 & 66.56 & 59.62 & 45.33 & 58.67 \\
1990 & 76.43 & 67.28 & 91.76 & 67.78 & 70.84 & 63.28 & 45.90 & 64.26 \\
2000 & 64.74 & 54.79 & 86.62 & 57.97 & 74.36 & 66.29 & 46.27 & 70.01 \\
2001 & 63.88 & 54.40 & 86.76 & 57.36 & 74.60 & 66.47 & 46.51 & 70.57 \\
2002 & 63.00 & 54.13 & 86.79 & 56.64 & 74.81 & 66.64 & 46.83 & 71.10 \\
2003 & 62.10 & 53.91 & 86.76 & 55.87 & 75.00 & 66.82 & 47.24 & 71.60 \\
2004 & 61.24 & 53.70 & 86.69 & 55.15 & 75.18 & 67.00 & 47.72 & 72.06 \\
2005 & 60.45 & 53.46 & 86.60 & 54.51 & 75.35 & 67.19 & 48.25 & 72.48 \\
2006 & 59.41 & 52.86 & 87.09 & 53.849 & 75.51 & 67.39 & 48.80 & 72.87 \\
2007 & 58.42 & 52.30 & 87.43 & 53.27 & 75.66 & 67.58 & 49.36 & 73.22 \\
2008 & 57.45 & 51.82 & 87.65 & 52.76 & 75.80 & 67.78 & 49.89 & 73.55 \\
2009 & 56.48 & 51.43 & 87.79 & 52.26 & 75.95 & 67.96 & 50.39 & 73.86 \\
2010 & 55.52 & 51.10 & 87.86 & 51.78 & 76.10 & 68.15 & 50.85 & 74.15 \\
2011 & 54.59 & 50.60 & 88.22 & 51.39 & 76.25 & 68.33 & 51.28 & 74.44 \\
2012 & 53.69 & 50.25 & 88.46 & 51.03 & 76.41 & 68.51 & 51.70 & 74.71 \\
2013 & 52.86 & 49.95 & 88.55 & 50.70 & 76.58 & 68.68 & 52.12 & 74.98 \\
2014 & 52.09 & 49.60 & 88.45 & 50.40 & 76.75 & 68.86 & 52.55 & 75.24 \\
2015 & 51.41 & 49.15 & 88.15 & 50.12 & 76.93 & 69.03 & 52.99 & 75.50 \\
2016 & 50.91 & 48.93 & 88.09 & 49.85 & 77.12 & 69.19 & 53.43 & 75.76 \\
2017 & 50.43 & 48.54 & 87.77 & 49.50 & 77.31 & 69.36 & 53.88 & 76.01 \\
\hline
\end{tabular}

Not: Dünya Bankası Online Veri Tabanı'ndan doğrudan alınmıştır, 2019.

Tablo 3 bebek ölüm oranlarının ortalamasının düşükten yükseğe doğru sıralanmasında Meksika, Türkiye, Endonezya ve Nijerya'nın; yetișkin ölüm oranlarında ise Türkiye, Meksika, Endonezya ve Nijerya'nın olduğunu göstermektedir. Belirtilen zaman dilimi içerisinde hem bebek ölüm oranlarındaki (12.66 kat) hem de yetişkin ölüm oranlarındaki (7.37 kat) en yüksek düşüşler, Türkiye'de kaydedilmiştir. 
Tablo 3.

Bebek ve yetişkin ölüm oranları: 1970-2017

\begin{tabular}{ccccccccc}
\hline \multirow{2}{*}{ Y1llar } & \multicolumn{3}{c}{ Bebek ölüm oranı (1.000 canlı doğum başına) } & \multicolumn{3}{c}{ Yetişkin ölüm oranı (toplam, 1.000 yetişkin) } \\
& Meksika & Endonezya & Nijerya & Türkiye & Meksika & Endonezya & Nijerya & Türkiye \\
\hline 1970 & 76.7 & 112.7 & 168.2 & 126.6 & 497.124 & 520.786 & 877.749 & 506.577 \\
1980 & 55 & 84.9 & 126.6 & 89.3 & 427.468 & 439.853 & 786.868 & 425.58 \\
1990 & 36.3 & 61.8 & 125.6 & 55.4 & 331.15 & 398.57 & 774.314 & 358.863 \\
2000 & 22.5 & 40.9 & 111.6 & 31.9 & 259.325 & 381.509 & 812.738 & 291.437 \\
2001 & 21.3 & 39.3 & 108.6 & 29.9 & 255.823 & 382.844 & 817.967 & 282.383 \\
2002 & 20.3 & 37.7 & 105.6 & 28.1 & 252.32 & 384.177 & 823.197 & 273.329 \\
2003 & 19.3 & 36.2 & 102.5 & 26.3 & 250.519 & 382.707 & 813.584 & 267.939 \\
2004 & 18.4 & 36 & 99.4 & 24.6 & 248.718 & 381.237 & 803.973 & 262.548 \\
2005 & 17.6 & 33.5 & 96.2 & 23.1 & 246.917 & 379.767 & 794.36 & 257.157 \\
2006 & 16.9 & 32.2 & 93 & 21.6 & 245.116 & 378.297 & 784.748 & 251.767 \\
2007 & 16.3 & 30.9 & 89.9 & 20.2 & 243.314 & 376.828 & 775.135 & 246.376 \\
2008 & 15.8 & 29.8 & 86.8 & 18.8 & 240.663 & 373.911 & 767.543 & 241.683 \\
2009 & 15.3 & 28.6 & 83.9 & 17.6 & 238.01 & 370.994 & 759.951 & 236.99 \\
2010 & 14.9 & 27.5 & 81 & 16.4 & 235.358 & 368.078 & 752.358 & 232.297 \\
2011 & 14.5 & 26.4 & 78.3 & 15.3 & 232.705 & 365.161 & 744.766 & 227.603 \\
2012 & 14.1 & 25.4 & 75.7 & 14.3 & 230.053 & 152.351 & 737.174 & 222.909 \\
2013 & 13.7 & 24.5 & 73.3 & 13.3 & 227.262 & 150.122 & 728.925 & 74.33 \\
2014 & 13.2 & 23.7 & 71 & 12.4 & 80.698 & 147.893 & 720.677 & 72.93 \\
2015 & 12.7 & 22.9 & 68.7 & 11.6 & 79.743 & 145.664 & 712.429 & 71.53 \\
2016 & 12.2 & 22.2 & 66.6 & 10.8 & 78.787 & 143.435 & 704.181 & 70.13 \\
2017 & 11.5 & 21.4 & 64.6 & 10 & 77.831 & 141.206 & 695.932 & 68.731 \\
\hline
\end{tabular}

Not: Dünya Bankası Online Veri Tabanı’ndan doğrudan alınmıştır, 2019.

Tablo 3 içerisindeki bilgilere ilave olarak temiz su, güvenilir olmayan temizlik ve hijyen eksikliğine bağlı ölüm oranları en yüksek Nijerya'da görülmektedir. 2016 yılı verileri Meksika, Endonezya, Nijerya ve Türkiye'de belirtilen sağlık koşullarına bağl1 100.000 kişi başına ölüm oranlarının sırasıyla 1.1, 7.1, 68.6 ve 0.3 olduğuna işaret etmektedir (Dünya Bankası, 2019).

\section{Ampirik Literatür Seçkisi}

Ekonomik büyüme ile sağlık parametreleri arasındaki ilişkiyi araştırmak için literatürde birçok kuramsal ve ampirik araştırmanın yapıldığı görülmektedir. Bu bağlamda, sağlı parametrelerini hesaba katmak amacıyla ekonomik büyümenin üretim fonksiyonu modelleri genişletilmiştir. Bazı araştırmacılar, ülkelerin sağlık koşullarının iyileştirilmesinin gelirde artış sağladığını, çünkü daha sağlıklı bir nüfusun beşeri sermayenin verimliliğini artırdığını, sağlıklı çalışanların daha yetenekli, üretken ve verimli olduklarını, dolayısıyla daha yüksek gelir elde ettiklerini savunmuşlardır. Sonuç olarak, sağlığın büyüme üzerinde olumlu ve belirgin bir etki yarattığı ifade edilmiştir. Diğer bazı araştırmacılar ise, yaşam beklentisi süresindeki artışların hızlı nüfus artışlarına neden olduğunu, bu doğrultuda üretim faktörlerinin (arazi, sermaye vb.) azalmasına bağlı olarak ekonomik büyümenin daha düşük düzeylerde seyredeceğini vurgulamışlardır. Ekonomik büyümenin çıtı 
olarak ele alındığı bu düşünce sistematiği literatürün geniş bir kısmını kapsamaktadır. Bu bağlamda, Ak (2012); Ay, Kızılkaya ve Koçak (2013); Bloom vd. (2001); Bloom, Canning ve Sevilla (2004); Chakraborty (2004); Çetin ve Ecevit (2010); Maisonneuve ve Oliveira Martins (2013); Odubunmi, Saka ve Oke (2012); Selim, Uysal ve Eryiğit (2014); Taban (2006); Tıraşoğlu ve Yıldırım (2012); Yumuşak ve Yıldırım (2009) tarafindan yapılan araştırmalar ampirik literatürün örneklerini oluşturmaktadır.

Bloom vd. (2001) ile Bloom vd. (2004) tarafindan 104 örneklem kümesi kullanılarak 1970-1990 ve 1960-1980 dönemleri için yapılan araştırmada, sağlığın ekonomik büyüme üzerindeki etkisi üretim fonksiyonu varsayımı altında ele alınmıştır. Her iki araştırmadan ulaşılan temel sonuç, sağlığın toplam büyüme üzerindeki etkisinin olumlu, büyük miktarda ve istatistiki olarak önemli bir etki yaratması olmuştur. Chakraborty (2004) 19701990 döneminde 95 ülke üzerine yaptığ çalışmasında, yaşam süresinin iyileştirilmesi ve ölüm risklerinin azaltılması yoluyla sağlık koşullarındaki gelişmelerin, büyüme üzerindeki etkilerini incelemiştir. Sonuçlar, sürekli bir ekonomik büyümenin ön koşulu olarak sağlık yatırımlarına işaret etmiştir. Özellikle, ölüm oranlarının yüksek olduğu ülkelerde tasarruf ve yatırım oranlarının düşük olduğu ifade edilmiştir.

Taban (2006) tarafından Türkiye üzerine yapılan çalışmanın ampirik kanıtları, 1968-2003 sürecinde GSYH ile sağlık kurumları sayısı arasında nedensellik etkileşimi bulunmadı̆̆ının; ancak, diğer sağlık parametrelerini içeren yaşam beklentisi süresi, sağlık personeli başına düşen kişi sayısı ve sağlık kurumlarındaki yatak sayıları ile GSYH arasında geri-besleme etkisini yansıtan nedensellik ilişkisinin bilgisini vermiştir. Yumuşak ve Yıldırım (2009) Türkiye örneğinde yaptıkları analiz sonuçlarında, 1980-2005 dönemi içerisinde sağlık harcamalarından gayri safi milli hâsıla (GSMH) doğru tek yönlü, küçük ve negatif etkili nedensellik ilişkisinin varlığı ile yaşam beklentisinden GSMH'ye giden tek yönlü nedensellik ilişkisini bulmuşlardır. Çetin ve Ecevit (2010) tarafından yapılan çalışmanın sonuçlarında, Ekonomik Kalkınma ve İşbirliği’ne (Organisation for Economic Co-operation and Development; OECD) üye 15 ülkede 1990-2006 zaman aralığında GSYH ile sağlık harcamaları arasında istatistiki olarak anlamsız bir ilişkiye ulaşılmıştır.

Ak (2012) Türkiye özelinde ulaştığı sonuçlarda, büyüme ve sağlık harcamaları arasında uzun vadede bir ilişki bulunduğunu, ancak kısa dönemde bir ilişki bulunmadığını göstermiştir. Odubunmi vd. (2012) 1970-2009 dönemi için Nijerya'da büyüme ve sağlı harcamaları arasındaki etkileşimi inceledikleri araştırmalarında, GSYH, sağlık harcamaları, dış yardımlar, toplam tasarruf ve nüfus arasında uzun vadeli bir ilişkiye ulaşmışlardır. Tıraşoğlu ve Yıldırım (2012) tarafından 2006-2012 zaman aralığında Türkiye örneğinde yapılan araştırmada, ekonomik büyüme ve sağlık harcamaları arasında uzun vadeli bir etkileşim görülmüştür. Ay vd. (2013) tarafından 1968-2006 dönemi için Türkiye kapsamında yapılan çalışmadan ulaşılan bulgularda, yataklı ve yataksız sağlık kurumu değişkenleri ile GSYH arasında pozitif yönde bir ilişki olduğu, sağlık memuru başına kişi sayısı ile GSYH arasında ise ilişki olmadığı sonuçlarına ulaşılmıştır.

Maisonneuve ve Oliveira Martins (2013) yaptıkları araştırmanın sonuçlarında, 2010 yılından 2060 yılına kadar uzun dönemli sağlık harcamalarının projeksiyonlarını önermişlerdir. Bu kapsamda, uzun dönem sağlık harcamaları ile ilgili olarak, yaş bağımlılık sayısının belirleyicileri tahmin edilmiştir. Buna göre, OECD ülkelerinde toplam uzun dönemli sağlık harcamalarının maliyeti ve maliyet baskısı senaryolarında, GSYH'yi sırasıyla yaklaşık \%3.3 ve \%7.7 artıracağı öngörülmüştür. Aynı dönem için BRICS ülkelerinde ise, sağl1k harcamalarının GSYH'yi \%2.8 ve \%7.3 oranında artıracağ1 tespit edilmiştir. Selim vd. (2014) ise çalışmalarında, 2001-2011 dönemi için 27 AB ülkesinde ve Türkiye'de sağlık harcamalarının ekonomik büyümeyi kısa ve uzun vadede etkilediğinin ampirik kanıtlarına ulaşmışlardır.

Literatürün güncel ve daha az kısmını oluşturan bir diğer alanı ise, ekonomik büyümenin sağlık parametreleri üzerindeki etkisinin açıklandığı çalışmalardır. Ekonomik büyümenin, özellikle gelişmemiş ve azgelişmiş ülkelerde insanların yaşam standartlarını yükselterek toplumların sağlık koşullarını iyileştirdiği iddia edilmektedir. Yapılan bu çalışmalarda sağlık çıktıları olarak yaşam beklentisi, bebek, çocuk ve yetişkin ölüm oranları, doğum oranları, sağlı sektörünün işleyişine ilişkin göstergeler (sağlık çalışanı sayısı, sağlık harcamaları vb.), ölüm sebepleri ve hastalık türleri gibi parametrelerin kullanıldığı görülmektedir. Baltagi ve 
Moscone (2010); Brenner (2005); Cole (2019); Gallardo-Albarrán (2018); Kyriopoulos, Nikoloski ve Mossialos (2019); Mehrara, Fazaeli, Fazaeli ve Fazaeli (2012); Novignon, Olakojo ve Nonvignon (2012); Rad vd. (2013); Rezaei vd. (2016); Samadi ve Rad (2013); Spiteri ve von Brockdorff (2019); Wang ve Granados (2019) tarafından yapılan çalışmalar, literatürün ikinci çalışma alanı için sunulan örneklerdir.

Brenner (2005) çalışmasında, ABD'de 20. yüzyıl boyunca “ekonomik büyüme, ölüm oranlarındaki düşüşün temel nedenidir" hipotezini araştırmıştır. Sonuçlar, GSYH'nin orta ve uzun vadede ölüm oranları ile güçlü bir şekilde ters orantıl1, kısa vadede ise doğru orantılı olduğunu göstermiştir. Aynı zamanda kümülatif olarak en az on yıldan uzun bir sürede ekonomik büyüme, 1901-2000 boyunca ölüm oranındaki düşüşün ana faktörü olmuştur. Baltagi ve Moscone (2010) 20 OECD ülkesi kapsamında 1971-2004 dönemi için yaptıkları araştırmanın sonuçlarında, sağlık harcamaları ile belirleyicilerinin çoğunun sabit olmadığını ve uzun dönemde birbirleri ile bağlantılı olduklarının; sağlık hizmetlerinin çok küçük bir esnekliğe sahip olduğunun; gelir dışındaki belirleyicilerden, gençlerin yüzdesinin sağlı harcamalarındaki değişimleri açıklamadaki rolünün kanıtlarını sunmuşlardır.

Novignon vd. (2012) 1995-2010 yılları arasında Sahra-altı Afrika ülkelerinde sağlık harcamalarının sağlık çıktıları üzerindeki etkilerini incelemişlerdir. Sonuçlar, sağlık harcamalarının hem doğumdaki yaşam süresini iyileştirerek, hem de ölüm ve bebek ölüm oranlarını azaltarak sağlık durumunu önemli ölçüde etkilediğini göstermiştir. Aynı zamanda kamu ve özel sağlık harcamalarının (kamu sağlık harcamaları nispeten daha yüksek bir etkiye sahip olmasına rağmen), sağlık durumu ile güçlü bir şekilde pozitif ilişki içerisinde olduğu belirtilmiştir. Mehrara vd. (2012) çalışmalarında, kamu harcamaları, özel harcamalar ve yaşam süresini içeren toplam sağlık harcamaları ile GSYH arasındaki etkileşimi 1995-2005 döneminde MENA ülkeleri için test etmişlerdir. Eşbütünleşme analizi sonuçlarına göre, değişkenlerin uzun dönemde birbirleri ile etkileşim gösterdiği tespit edilmiştir.

Rad vd. (2013) tarafından 1995-2010 döneminde Doğu Akdeniz ülkeleri üzerine yapılan araştırmanın sonuçları, kamu sağlık harcamaları ile bebek ölümleri arasında net ve güçlü bir negatif korelasyon; özel sağlık harcamaları ile bebek ölümleri arasında ise pozitif yönde bir korelasyon olduğunu açıklamıştır. Bununla birlikte, kamu sağlık harcamalarının sağlık durumunda iyileşmeye yol açtığ ; özel sağlık harcamaları ile sağlık durumu arasında anlamlı bir ilişki kurulamadığı, dolayısıyla kamu sağlık harcamalarının artmasının bebek ölüm oranlarını azalttığı söylenmiştir. Samadi ve Rad (2013) 1995-2009 dönem aralığında Ekonomik İşbirliği Teşkilatı'na üye gelişmekte olan ülkelerde, sağlık harcamalarının belirleyicilerini araştırmışlardır. Bulgularda, sağlık harcamaları ile GSYH, 15 yaş altındaki nüfus, 65 yaş üstündeki nüfus, hekim sayısı ve kentleşme değişkenleri arasında uzun vadeli ilişkiler olduğu elde edilmiştir. Kısa vadede ise 65 yaş üstündeki nüfus oranı hariç, diğer değişkenlerin sağlık harcamaları ile ilişkili olduğu bulgularına ulaşılmıştır.

Rezaei vd. (2016) 1978-2011 sürecinde İran'da sağlık harcamalarının belirleyicilerini incelemişlerdir. Sonuçlarda, GSYH, okuma yazma bilmeme oranı, kentleşme ve hekim sayısının sağlı harcamalarındaki artışın arkasındaki itici güçler olduğu belirlenmiştir. Gallardo-Albarrán (2018) 36 ülke örneğinde sağlıktaki eşitsizliklerin ekonomik eşitsizlik üzerindeki etkilerini, eğitim ve yaşam beklentisini içeren bir çerçevede ele almıştır. Temel sonuçlar, sağlığın tarihsel olarak ülkeler arasında önemli bir gelir değişimi kaynağı olduğunu göstermiştir. Ayrıca, 1900 ve 1955 yıllarında, yaşam beklentisi farklılığının yaklaşık olarak \%20'yi ve ülke içi gelir eşitsizliğinin 1/4'ni oluşturduğunu; ülkeler arası gelir eşitsizliğinin yaklaşık \%20 daha yüksek bulunduğunu; 1955'ten sonra sağlık yakınsama süreci yaşanmadığını; 20. yüzyılın ortaları ile 1990 yılı arasındaki ülkeler arası sağlık farklılıklarının azaltılmasının, önemli bir gelir yaklaşımı kaynağı olduğunu; sağlığın gelir seviyesi için göreceli öneminin son üç yılda, sağlık yakınsama oranındaki bir yavaşlama nedeniyle sabit kaldığını tespit etmiştir.

Cole (2019) çalışmasında, gelişmekte olan 134 ülke ekonomisi için 1970-2015 döneminde ekonomik büyümenin sağlığı iyileştirdiğini bebek ölümlerini, yaşam beklentisini, kalori tüketimini temsil eden sağlık çıktıları ile ortaya koymuştur. Büyümenin, sağlık çıktıları üzerindeki en yüksek etkisi bebek ölüm oranlarında 
görülmüştür. Ayrıca, GSYH'nin, bebek ölüm oranlarını düşürdüğüne, yaşam beklentisini ve kalori alımını artırdığına ulaşılmıştır. Bununla birlikte, ekonomik büyümenin azalan getirilerinin olduğu, yani ülkeler daha varlıklı hale geldikçe, büyümenin sağlık için yararlarının azaldığı belirtilmiştir. Kyriopoulos vd. (2019) çalışmalarında, 2008-2015 döneminde Yunanistan'da görülen ekonomik resesyonun yenidoğan sağlığ1 üzerindeki etkilerini incelemişlerdir. Sonuçlarda, gebelik sırasındaki iş döngüsü dalgalanmaları ile sosyoekonomik gruplar arasında yenidoğan sağlığı arasındaki ilişkide heterojenlik olduğu raporlanmıştır. Ekonomik krizin doğum göstergeleri üzerindeki etkisinin, düşük sosyo-ekonomik statüdeki çocuklar için daha zararlı olduğu; bu durumun ise düşük ve yüksek sosyo-ekonomik statüdeki ailelerinin çocukları arasındaki doğum ağırlığı farkının genişlemesine neden olduğu belirlenmiştir.

Spiteri ve von Brockdorff (2019) ekonomik gelişmenin sağlık sonuçları üzerindeki etkisini, 2003-2014 dönemi için 27 Avrupa ülkesi örneklem kümesi kapsamında ele almışlardır. Sonuçlar, değişkenler arasında istatistiki olarak anlamlı ters-U şeklindeki değişen bir ilişkinin varlığını göstermiştir. Bu bağlamda, gelir arttıkça, ölüm oranlarının ilk önce yükseldiği, daha sonraki gelişim seviyelerinde ise düştügü gözlemlenmiştir. Sonrasında, mikroekonomik bir tüketici tercihi modeli kullanılarak ters-U biçimli gelir-ölüm ilişkisinin kalıcıllğı, bu ilişkinin sağlık yatırımlarının ölçeğe göre artan getiri varsayımı altında açıklanmıştır. Bulgularda, sağlık teknolojilerine yapılan yatırımın önemi ve özellikle büyümekte olan ülkelerdeki kamu sağlık sistemlerinde, ekonomik büyümeyi artırma çabaları ile birlikte iyileştirmelerin devam ettiği vurgulanmıştır.

Wang ve Granados (2019) 2011, 2012, 2013 ve 2015 yılları için toplam 42.000 gözlemi kapsayan, 45 yaş ve üstü yetişkinle yapılan anketleri kullanarak Çin'deki ekonomik koşullar ve ruh sağlığı arasındaki ilişkiyi araştırmışlardır. Çalışmada ruh sağlığı; depresyon belirtileri, bilişsel bozulma ve yaşam memnuniyetsizliği göstergeleri ile değerlendirilmiştir. Yüksek depresyon semptomları, zihinsel sağlığın bozulmasına bağlı olarak GSYH büyüme oranları ile ilişkili bulunmuştur. Aynı zamanda etkilerin küçük ve hem erkeklerde hem de kadınlarda oldukça benzer şekilde olduğu belirlenmiştir.

Acemoglu ve Johnson (2007); Doğan (2016); Chaabouni ve Saidi (2017) tarafından yapılan çalışmalarda ise, ekonomik büyüme ve sağlık arasındaki etkileşimlerin farklı denklemler aracılığıyla her iki değişkenin de açıklanan değişken olarak ele alındığı görülmektedir.

Acemoglu ve Johnson (2007) çalışmalarında, sağlık parametreleri ile ekonomik performans arasındaki ilişkiyi farklı ekonometrik modeller eşliğinde tahmin etmişlerdir. Sonuçlarda, ölüm oranlarının yaşam beklentisi üzerinde 1940 yılında büyük bir etkiye sahip olduğu, ancak bu etkinin 1940 yılından önce olmadığ1; yaşam beklentisindeki \%1' lik bir artışın, nüfusta $\% 1.7$ ilâ \%2 bant aralığında bir artışa yol açtığı; yaşam beklentisinin, GSYH'de çok küçük bir etki yarattığı ifade edilmiştir. Ancak, yaşam beklentisindeki yüksek artışın kişi başına geliri artırdığına dair herhangi bir kanıt bulunamamıştır.

Doğan (2016) tarafından 1960-2013 dönemi için Türkiye örneklem kümesinin kullanıldığı çalışmada bulgular, GSMH ile toplam sağlık durumu ve istihdamı ifade eden sağlı harcamaları arasında geri-besleme etkisini yansıtan doğrusal olmayan nedensellik ilişkisine işaret etmiştir. Chaabouni ve Saidi (2017) tarafindan 19952013 döneminde düşük, orta ve yüksek gelir grubuna dâhil toplam 51 ülke örnekleminde yapılan araştırmanın bulguları, sağlık harcamaları ile ekonomik büyüme arasında geri-besleme yönlü bir nedensellik etkisinin bilgisini; ayrıca, sağlığın GSYH’de önemli bir rol oynadığını göstermiştir.

\section{Ampirik Analiz}

\section{1. Örneklem grubu ve veri seti.}

$\mathrm{Bu}$ araştırmanın amac1, 2000-2016 zaman aralığı içerisinde ekonomik büyüme ve sağlı harcamaları arasındaki olası etkileşimi Meksika, Endonezya, Nijerya ve Türkiye ülkeleri örneklem kümesi kapsamında incelemektir. 
Amaç doğrultusunda bu araştırmada Baltagi ve Moscone (2010) ile Maisonneuve ve Oliveira Martins (2013) tarafından oluşturulan sağlık harcama modelleri dikkate alınmıştır. Bu kapsamda değişkenler arasındaki ilişkilerin tahmin işlemleri için kurulan lineer panel regresyon modeli aşağıdaki gibidir:

$h \exp _{i t}=\partial_{i}+d_{t}+\beta_{i}^{\prime} X_{i t} y b_{i t}+\varepsilon_{i t}$

Modeldeki $h \exp _{i t}, t$ zamanda $i$ inci ülkedeki kişi başına sağlık harcamalarına; $X_{i t}$, sağlık harcamalarını açıklayan gelir, kamu harcamaları, yaşam beklentisi, nüfus ve bağımlılık oranlarını içeren $k \times 1$ değișkenlerine işaret etmektedir. $\partial_{i}$, ülkeye özgü sabit terimini; $d_{t}$, zaman kukla değişkenini; $\varepsilon_{i t}$ ise hata terimini açıklamaktadır.

Ekonomik büyüme ve sağlk harcamaları arasındaki ilişkileri sınamaya yönelik olarak yapılan ampirik analizde, açıklayıcı değişkenlerin bilgisini veren $X_{i t}^{\prime}$ nin açık şekli için model yeniden kurulmuştur:

$h \exp _{i t}=\partial_{i t}+\beta_{1} g d p_{i t}+\beta_{2} \exp _{i t}+\beta_{3} \operatorname{lexp}_{i t}+\beta_{4}$ pop $_{i t}+\beta_{5} o d r_{i t}+\beta_{6} y d r_{i t}+\varepsilon_{i t}$

$i=1, \ldots, 4$ ve $t=1, \ldots, 17$

Denklemde yer alan hexp, kişi başına sağlık harcamalarını (satın alma gücü paritesi, \$); $g d p$, kişi başına gayri safi yurtiçi hâsılayı (satın alma gücü paritesi, \$); pexp, kamu sağlık harcamalarını (toplam kamu harcamalarının \%'si); lexp, doğumda yaşam beklentisini (toplam, y1l); pop, nüfusu (toplam); odr, yaşlı bağımlılık oranını (çalışma yaşı nüfusunun \%'si); $y d r$, genç bağımlılık oranını (çalışma yaşı nüfusunun \%'si) gösteren değiş̧kenlerdir. $\beta_{1}, \beta_{2}, \beta_{3}, \beta_{4} \beta_{5}$ ve $\beta_{6}$ değişkenlere ait parametre katsayılarıdır. Tüm değişkenler, logaritmik form yapısında model içerisine dâhil edilmiştir.

Alt simge $i$, Meksika, Endonezya, Nijerya ve Türkiye yatay kesit birimlerini; $t$ simgesi ise 2000-2016 inceleme dönemindeki 17 yıllık zaman aralığını belirten notasyonlardır. $n=4$ ve $T=17$ olmak üzere, $N=68$ gözleme sahip dengeli bir panel modeli içerisindeki değişkenlerin tanımlayıcı istatistiklerinin raporlandığı Tablo 4 aşağıdadır.

Tablo 4.

Değişkenlerin tanımlayıcı istatistikleri

\begin{tabular}{lccccccc}
\hline \multicolumn{1}{c}{ İstatistikler } & lnhexp & lngdp & lnpexp & lnlexp & lnpop & lnodr & lnydr \\
\hline Ortalama değer & 5.9284 & 9.1137 & 1.8702 & 4.1860 & 18.675 & 2.0542 & 3.9572 \\
En büyük değer & 6.9932 & 10.1716 & 2.4926 & 4.3453 & 19.382 & 2.4794 & 4.4230 \\
En küçük değer & 4.4105 & 7.8007 & 0.5314 & 3.8344 & 17.962 & 1.6320 & 3.6353 \\
Standart hata & 0.7765 & 0.6058 & 0.5278 & 0.1699 & 0.4506 & 0.2740 & 0.2763 \\
Çarpıklık (skewness) & -0.2394 & -0.2728 & -0.6531 & -1.0044 & 0.0127 & -0.3615 & 0.8750 \\
Basıklık (kurtosis) & 1.7714 & 2.1443 & 2.4431 & 2.3851 & 1.7831 & 1.8686 & 2.0979 \\
Jarque-Bera & 4.9263 & 2.9183 & 5.7130 & 12.5064 & 4.1973 & 5.1076 & 10.9826 \\
Olasılık & $(0.0851)$ & $(0.2324)$ & $(0.0574)$ & $(0.0019)$ & $(0.1226)$ & $(0.0777)$ & $(0.0041)$ \\
Gözlem sayısı & 68 & 68 & 68 & 68 & 68 & 68 & 68 \\
\hline
\end{tabular}

Denklem (2) içerisinde yer alan her bir katsayının beklenen işareti, pozitif yönlüdür. Bu doğrultuda, $\beta_{1}, \beta_{2}, \beta_{3}, \beta_{4} \beta_{5}$ ve $\beta_{6}$ parametre katsayıları için araştırmanın hipotezleri kuramsal temelli beklentiler doğrultusunda aşağıdaki gibi kurulmuştur:

Hipotez 1: $\beta_{1}, \beta_{2}>0$ ve $0<\beta_{1}, \beta_{2}<1$ 
Sağlık harcamalarının gelir esnekliği $\left(\beta_{1}, \beta_{2}>0\right)$, ekonomik büyüme ve sağlık harcamaları arasındaki pozitif bir korelasyonu temsil etmektedir. Aynı zamanda $\beta_{1}$ ve $\beta_{2}$ 'nin 0 ile 1 aralığında $\left(0<\beta_{1}, \beta_{2}<1\right)$ olması, sağlık harcamalarının risk paylaşım mekanizmasını açıklamaktadır.

Hipotez 2: $\beta_{3}, \beta_{4}, \beta_{5}, \beta_{6}>0$

Model içerisinde yer alan yaşam beklentisi, nüfus, yaşlı ve genç bağımlılık oranlarında \%1'lik meydana gelen pozitif yönlü değişimlerin, sağlık harcamaları üzerinde pozitif yönde etkiler yaratması beklenmektedir.

Değişkenlere ait 2000-2016 inceleme dönemini kapsayan veri seti, Dünya Bankası'nın Dünya Gelişme Göstergeleri online veri tabanından derlenmiştir. Değişkenler arasındaki olası ilişkilerin tahmin işlemleri, Stata ve Eviews paket programları kullanılarak yapılmıştır.

\subsection{Metodoloji.}

MINT ülkeleri örneklem kümesi kapsamında ekonomik büyüme ve sağlık harcamaları arasındaki olası ilişkilerin sınanmasına yönelik olarak yapılan araştırmada, statik panel veri analizi kullanılmıştır.

Zaman serileri ile yatay kesit metodolojilerine göre, araştırmacıya öncelikle daha kapsamlı veri setleri ile analiz yapma imkânı tanıyan panel veri analizi, "aynı yatay kesit birimlerine ait gözlem değerlerinin, belirli bir zaman aralığında birleştirilmesidir” şeklinde tanımlanmaktadır (Gujarati, 2004, s. 636).

Panel veri modelinin temel çerçevesi (Green, 2010, s. 345-346):

$y_{i t}=x_{i t}^{\prime} \beta+z_{i}^{\prime} \alpha+\varepsilon_{i t}$

$y_{i t}=x_{i t}^{\prime} \beta+c_{i}+\varepsilon_{i t}$

$i=1, \ldots, N$ ve $t=1, \ldots, T$ şeklinde kurulmaktadır.

Modeldeki $x_{i t}$, kesme terimi içermeyen $K$ bağımsız değişkenlerdir. Birim etki (heterojenlik) $z_{i}^{\prime} \alpha$ ile gösterilmektedir; $z_{i}$, kesme terimi ile gözlemlenebilen veya gözlemlenemeyen birim ya da grup değişkenlerini içerdiği durumlarda, $t$ zaman içerisinde değişmeyecek şekilde ele alınmaktadır. Yukarıdaki model, klasik regresyon modeli eşitliğini belirtmektedir. Eğer $z_{i}$, tüm birimlerde gözlemleniyorsa, model sıradan lineer bir model şeklinde düşünülmelidir ve En Küçük Kareler tahmincisi tercih edilmelidir. Ancak sorunların çoğu, $c_{i}^{\prime}$ nin gözlemlenemediği durumlarda ortaya çıkmaktadır. $i$, yatay kesitleri; $t$ zamanı açıklayan simgelerdir. Bu kapsamda, eğer yatay kesit birimleri tüm zaman dilimleri süresince gözlemlenebiliyorsa "dengeli panel"; eğer bazı yatay kesit birimlerinde zaman süreci kayıpları varsa "dengesiz panel” kullanılmaktadır.

Panel veri analizi modelleri, statik ve dinamik modeller şeklinde iki temel kategoriye ayrılmaktadır. Statik panel veri modelleri, model içerisinde değişkenlere ait geçmiş devre değerlerinin olmadığı modellerdir. Dinamik panel veri modelleri ise, model içerisinde gecikmeli değişkenlerin eklenmesi ile kurulan modellerdir (Çağlayan Akay, 2015, s. 81).

Araştırmada kullanılan statik panel veri modeline ait panel regresyon denklemi aşağıdaki şekilde ifade edilmektedir (Güriş, 2015, s. 5):

$Y_{i t}=\alpha_{i t}+\beta_{i t} X_{i t}+u_{i t}$

$Y_{i t}$ ve $X_{i t}: i=1, \ldots, N$ ve $t=1, \ldots, T$

Denklemde sabit parametre $\left(\alpha_{i t}\right)$ ve eğim parametresi $\left(\beta_{i t}\right)$ olmak üzere iki tane parametre vardır ve bu parametreler $k$ ile belirtilmektedir $(k=2)$. Hata terimi ise $u_{i t}$ 'dir.

$k=1,2, \ldots, K$ sayıda parametreyi açıklayan lineer bir panel veri denklemi:

$Y_{i t}=\alpha_{i t}+\beta_{2 i t} X_{2 i t}+\cdots+\beta_{k i t} X_{k i t}+u_{i t} \quad$ şeklinde açıklanmaktadır.

Denklem (6), toplamsal şekilde kısaltıldığında aşağıdaki gibi yazılmaktadır: 
Denklem 7'deki kesme terimi parametresi $\alpha_{i t}=\alpha+\mu_{i}+\lambda_{t}$ eşitliğini göstermektedir. Eşitlikteki $\alpha$, ortalama kesme terimi parametresini; $\mu_{i}$, birimlerin etkisini; $\lambda_{t}$, zaman etkisini vermektedir. Modeldeki tahminleme süreci; yalnızca birimleri barındırıyorsa zaman etkisi $\left(\lambda_{t}\right)$, yalnızca zaman etkisini barındırıyorsa birim etkisi $\left(\mu_{i}\right)$ model içerisinden uzaklaştırılmaktadır. Denklemdeki $\mu_{i}$ ve $\lambda_{t}$ terimleri sabit olduğunda model, "Kovaryans Modeli" şeklinde adlandırılmaktadır. $\mu_{i}$ ve $\lambda_{t}$ terimleri tesadüfi değişken olduğunda ise model "Hata Bileşenleri Modeli" şeklinde tanımlanmaktadır. Kovaryans modelinde, birim ve zaman etkiler sabit olmaktadır. Modeldeki birim ve zaman etkileri ifade eden terimler parametredir. Ancak hata bileşenleri modelinde, birim ve zaman etkileri gösteren terimler tesadüfi değişkendir. Bu yüzden kovaryans modeli "Sabit Etkiler veya Sabit Katsayılar Modeli", hata bileşenleri modeli ise "Rassal Etkiler veya Rassal Katsayılar Modeli” şeklinde adlandırılır.

\subsection{Bulgular.}

Araştırmanın ilk aşamasında, panel veri modelinin belirlenmesi amacına yönelik normal regresyon tahmincileri arasında seçim işlemleri yapılmıştır. Bu doğrultuda tahminciye yönelik seçim işlemleri için, klasik model, sabit katsayılar ve rassal katsayılar modelleri kurulmuştur. Klasik modelin geçerliliğinin sınanması için F, LR (olabilirlik oranı) ve LM (Lagrange çarpanı) testleri; sabit katsayılar ve rassal katsayılar tahmincilerini belirlemek için ise Hausman testi kullanılmıştır.

F, LR ve LM testleri sabit ve/veya rassal katsayılar tahmincilerine dayalı olarak kurulmaktadır. $H_{0}{ }^{\prime}$ in reddedilmesi "klasik model uygun değildir" hipotezini belirtmekte, ancak modelin sabit ya da rassal katsayılar tahmin sürecini yansıtmamaktadır. Hausman testinde ise, rassal katsayılar tahmincisi sabit katsayılar tahmincisine karşı sınanmaktadır. Hausman testinde "rassal katsayılar tahmincisi uygundur" şeklindeki $H_{0}$ temel hipotezi incelenmektedir. F, LR, LM testleri ile Hausman test bulguları Tablo 5 içerisinde raporlanmıştır.

Tablo 5 .

Tahminciler arasinda tercih işlemleri

\begin{tabular}{|c|c|c|c|}
\hline Testler & Birim etki ve/veya zaman etkisi & Birim etki & Zaman etkisi \\
\hline \multirow{2}{*}{ F testi } & & $\mathrm{F}(3,58)=24.72$ & $\mathrm{~F}(16,45)=0.59$ \\
\hline & 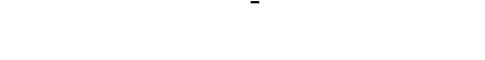 & $\mathrm{P}>\mathrm{F}=0.0000$ & $\mathrm{P}>\mathrm{F}=0.8747$ \\
\hline \multirow{2}{*}{ LR testi } & $\mathrm{LR}_{\text {birim-zaman }} x^{2}(2)=37.28$ & $\operatorname{chibar} 2(01)=35.62$ & $\operatorname{chibar} 2(01)=0.00$ \\
\hline & $\mathrm{P}>x^{2}=0.0000$ & $\mathrm{P}>=$ chibar $2=0.00$ & $\mathrm{P}>=$ chibar $2=1.00$ \\
\hline \multirow{2}{*}{ LM testi } & & $\operatorname{chibar} 2(01)=0.00$ & $\operatorname{chibar} 2(01)=0.00$ \\
\hline & & $\mathrm{P}>$ chibar2 $=1.000$ & $\mathrm{P}>$ chibar2 $=1.000$ \\
\hline \multirow{2}{*}{ Hausman testi } & $x^{2}(3)=34.23$ & & \\
\hline & Prob $>$ chi $2=0.0000$ & & \\
\hline
\end{tabular}

$F$ testi sınama bulgularında; $H_{0}$ temel hipotezi "birim etkilerin olmadığı bir diğer ifadeyle birim etki hata öğelerinin tümünün sıfira eşit olduğu" varsayımının reddedildiği görülmektedir. Bu kapsamda paneldeki birim etkilerin anlamlılığının bileşik hipotezle test edildiğini ifade eden $(3,58)$ serbestlik derecesine sahip $F$ istatistiğine ait olasılık değeri, modelde birim etkilerin varlığına işaret etmektedir. Birim etkilerin varlığı durumunda klasik model uygun değildir. $L R$ testi sınama bulguları, modelin birim ve zaman etkileri hakkında bilgi sunmaktadır. $L R$ test istatistiğine ait olasılık değerine göre, $H_{0}$ hipotezi "birim etkilerin standart hatalarının sıfıra eşit olduğu" reddedilmektedir. Bu doğrultuda modelde birim etkisinin geçerli, ancak zaman etkisinin geçerli olmadığı görülmektedir. $L M$ test istatistiğine ait olasılık değerine göre, zaman etkisinin 
varyansının sıfıra eşit olduğunu belirten $H_{0}$ temel hipotezi kabul edilmektedir. Dolayısıyla, uygun modelin klasik model olmadığı söylenmektedir.

Klasik modelin test edilmesi amacıyla yapılan F, LR ve LM sınamalarından ulaşılan temel bulgulara göre, ampirik analizde tercih edilecek tahmincinin klasik model olmadığ görülmektedir. Hausman test istatistiği bulguları, $H_{0}$ hipotezinin reddedildiğini ve rassal katsayılar modeline ait varsayımların yerine getirilmediğini göstermektedir. $H_{0}$ hipotezinin reddedilmesi, rassal katsayılar tahmincisinin hem yansız hem de tutarlı olmadığını, tahminci seçiminde sabit katsayılar modelinin kullanılması gerektiğini açıklamaktadır.

Kurulan sabit katsayılar modelinin yorumlanmasından önce, modelin etkinliğinin belirlenmesi amacıyla varsayımlardan sapmalara ait sınamalar yapılmıştır. Bu kapsamda, otokorelasyon, değişen varyans ve birimler arası korelasyon varsayımlarına ait istatistiksel anlamlılık testleri uygulanmıştır. Tahmin sürecinde karar verilen sabit katsayılar modeli için yapılan varsayımlardan sapmalara ait sınama bulguları Tablo 6 içerisine aktarılmıştır.

Tablo 6.

Varsaylmlardan sapmalara ait sinama bulguları

\begin{tabular}{ll}
\hline \multicolumn{1}{c}{ Varsayım } & \multicolumn{1}{c}{ Test istatistiği } \\
\hline Otokorelasyon varsayımı & Durbin-Watson test istatistiği DW $=2.0986$ \\
& Bhargava vd. test istatistiği LBI $=2.2985$ \\
Değişen varyans varsayımı & Wald test istatistiği $x^{2}(4)=74.09$ \\
& Prob $>x^{2}=0.0000$ \\
Birimler arası korelasyon & Breusch-Pagan test istatistiği LM $x^{2}(6)=12.637$ \\
& Prob $=0.0492$ \\
\hline
\end{tabular}

Kurulan modeldeki otokorelasyon bulguları incelendiğinde $D W$ ve $L B I$ test istatistik değerlerinin, sirasıyla, 2.10 ve 2.30 olduğu görülmektedir. Bulgular 1şığında, $D W$ ve $L B I$ istatistik değerlerine göre $H_{0}$ hipotezinin reddedilerek, modelde otokorelasyon sorunu olmadığına ulaşılmıştır. Her bir yatay kesit biriminin varyansının panelin ortalamasına eşit olduğunu gösteren Wald test istatistiği bulgularında, $H_{0}$ temel hipotezi reddedilmektedir. Bu kapsamda modelde birimlere göre değişen varyans problemi olduğu, varyansın sabit olmadığı anlaşılmaktadır.

Ampirik analizin $T>n$ koşulu altında birimler arasında korelasyonun sınanmasında, Breusch ve Pagan'ın (1980) geliştirdiği $\mathrm{CD}_{\mathrm{LM} 1}$ testi dikkate alınmaktadır. Bulgularda, birimler arasında korelasyon olmadığını belirten $H_{0}$ hipotezi reddedilmektedir. Bu doğrultuda, yatay kesit birimleri arasında kalıntıların birbirleri ile ilişki içerisinde oldukları görülmektedir. Ulaşılan bulgu, MINT ülkeleri arasında eşzamanlı ilişkinin varlığını göstermektedir. Ayrıca, seriye gelen bir şoktan ülkelerin tümünün etkilendiği bilgisini de sunmaktadır.

Kurulan sabit katsayılar modelindeki temel varsayımlara ait bulgular, bütüncül olarak incelendiğinde, modelde varyansın sabit olmadığı ve birimler arasında korelasyon olduğu, ancak otokorelasyon sorununun olmadığ 1 anlaşılmaktadır. Ulaşılan bulgulara göre, sabit katsayılar modelinde değişen varyans ve birimler arasında korelasyon sorunları varsayımı altında Driscoll-Kraay dirençli tahminci ile uygun düzeltmeler yapılmış, bulgular Tablo 7 içerisinde raporlanmıştır. 
Tablo 7.

Sabit katsayılar modeli için varsayımlardan sapmaların düzeltilmesi

\begin{tabular}{lccc}
\hline Inhexp & Katsayılar & $\begin{array}{c}\text { Drisc/Kraay } \\
\text { standart hata }\end{array}$ & $\mathrm{t}$-ist. $(|\mathrm{P}>\mathrm{t}|)$ \\
\hline lngdp & 1.1513 & 0.0667 & $17.26(0.000)$ \\
lnpexp & 0.5722 & 0.0685 & $8.35(0.004)$ \\
lnlexp & -1.5793 & 1.6836 & $-0.94(0.417)$ \\
lnpop & -1.3327 & 0.7123 & $-1.87(0.158)$ \\
lnodr & -4.7866 & 0.5494 & $-8.71(0.003)$ \\
lnydr & -3.6465 & 0.3523 & $-10.35(0.002)$ \\
C & 50.1294 & 6.6300 & $7.56(0.005)$ \\
& Tanımlayıc1 istatistikler & \\
$\mathrm{R}^{2}$ & 0.936 & & \\
$\mathrm{~F}_{\text {istatistiği }}$ & $\mathrm{F}(6,3)=806.16$ & \\
prob $>\mathrm{F}$ & 0.0001 & \\
\hline
\end{tabular}

Sabit katsayılar modeli bulguları, tanımlayıcı istatistiklerden $F(6,3)$ istatistiğinin 0.95 güven aralığında modelin bir bütün olarak anlamlılığına işaret etmektedir. Grup içi $R^{2}$ determinasyon katsayısı değerine göre, modeldeki açıklayıcı değişkenler sağlık harcamalarındaki değişkenliğin yaklaşık olarak \%94'ünü açıklamaktadır.

Değişen varyans ve birimler arasında korelasyon sorunları için hesaplanan $t$ istatistik değerlerine ve 0.05 anlam düzeyine göre; sağlık talebi fonksiyonunda çıktı olarak analize dâhil edilen sağlık harcamaları üzerinde GSYH, kamu harcamaları, genç ve yaşlı bağımlılığı değişkenlerinin etkileri istatistiksel olarak anlamlı; ancak yaşam beklentisi ile nüfus değişkenlerinin etkileri anlamsız çıkmıştır.

Denklem (2) içerisinde yer alan değişkenler için istatistiksel anlamlılık altında elde edilen bulgular doğrultusunda, aşağıdaki denkleme ulaşılmıştır:

$\operatorname{lnhexp}_{i t}=50.13+1.15 \operatorname{lngdp}_{i t}+0.57 \operatorname{lnpexp}_{i t}-4.79 \operatorname{lnodr}_{i t}-3.65 \operatorname{lny}_{\text {In }}$ It $_{i t}$

Modele ait tahmin sonuçlarının yer aldığı katsayılar tablosundan ulaşılan yukarıdaki denklem incelendiğinde; GSYH'nin ve kamu harcamalarının sağlık harcamalarını artırdığı, genç ve yaşlı bağımlılık oranlarının ise azalttığı görülmektedir. Buna göre GSYH ve kamu harcamaları \%1 arttığında, sağlık harcamaları sırasıyla ortalama \%1.15 ve \%0.57 artmakta; genç ve yaşlı bağımlılık oranları \%1 arttığında, sağlık harcamaları sırasıyla ortalama $\% 4.79$ ve $\% 3.65$ azalmaktadır.

\section{Sonuç ve Tartışma}

Bu araştırmada, ekonomik büyüme ile sağlık harcamaları arasındaki etkileşim MINT ülkeleri kapsamında ele alınarak 2000-2016 zaman aralığı içerisinde incelenmiştir. Amaç doğrultusunda, kişi başına sağlk harcamalarının çıktı olarak yer aldığı harcama modelinde, kişi başına GSYH, kamu sağlık harcamaları, yaşam beklentisi, nüfus, yaşlı ve genç bağımlılık oranı değişkenleri arasındaki olası ilişkilerin belirlenmesi için panel veri analizi yapılmıştır.

Birim etkili sabit katsayılar modeli için dirençli tahminci ile ulaşılan sonuçlar doğrultusunda, sağlık harcamaları üzerinde GSYH, kamu sağlık harcamaları, genç ve yaşlı bağımlılık oranlarının etkileri istatistiki olarak anlamlı; yaşam beklentisi ve nüfus değişkenlerinin etkileri ise anlamsız bulunmuştur. 
Sonuçlar değerlendirildiğinde; gelirdeki \%1 oranında bir artışın, sağlık harcamalarında \%1.15 oranında bir artış yaratması, sağlık harcamaları için gelir esnekliğinin 1'den yüksek olduğunu açıklamaktadır. Ulaşılan sonuç, araştırmanın örneklem kümesinde sağlık hizmetleri talebinin lüks bir mal olduğunu ve sağlık harcamalarının GSYH içindeki payının kişi başına düşen gelirle birlikte arttığını göstermektedir. Ayrıca, büyümeye yönelik olarak gelirin sağlık harcamalarının önemli bir belirleyici faktörü olduğuna işaret etmektedir. Kamu sağlık harcamalarındaki \%1 oranında bir artışın, sağlık harcamalarında kendinden daha düşük (\%0.57 oranında) bir etkiye sahip olması, sağlık yatırımlarından beklenen getirinin sağlanamadığına dikkat çekmektedir. Aynı zamanda hem sağlık politika yapıcıları, hem de sağlık çalışanları kişi başına sağlık harcamalarındaki risk mekanizmasını paylaşmaktadır. GSYH ile kamu sağlık harcamalarının, kişi başına sağl1k harcamaları üzerinde pozitif etki yaratması ampirik literatürde yer alan bazı çalışmaların sonuçları benzerlikler içermektedir. Sonuçlar, Chaabouni ve Saidi (2017); Cole (2019) Doğan (2016); Gallardo-Albarrán (2018); Mehrara vd. (2012); Novignon vd. (2012); Rad vd. (2013); Rezaei vd. (2016); Samadi ve Rad (2013) tarafindan yapılan çalışmalarla desteklenmektedir.

Nüfus ve yaşam beklentisi değişkenlerine ilişkin olasılık değerlerinin anlamsız olması, beklentileri karşılamayan bir sonuçtur. Genç ve yaşlı bağımlılık oranlarına ilişkin sonuçlarda, değişkenlerin sağlık harcamaları üzerindeki etkisinin anlamlı, ancak beklendiği gibi pozitif yönde çıkmadığı görülmektedir. Ulaşılan sonuç için bir açıklama olarak genç bağımlılık oranının, yaşlı bağımlılık oranından daha yüksek oranda sağlık harcamalarını azaltması literatürle bağdaşan bir sonuçtur. Çünkü demografik gösterge olarak incelenen bağımlılık oranlarında genç nüfusun, yaşlı nüfustan daha az sağlık harcaması yaptığı bilinmektedir.

Araştırmadan elde edilen sonuçlar, ekonomik büyümenin, kamu sağlık harcamalarının ve bağımlılık oranlarının sağlık harcamalarının belirleyicilerinden olduğunu kanıtlar niteliktedir. Bu bağlamda, ekonomik büyümenin toplumların sağlık profilinde iyileştirmeler yaratarak sağlık kalitesini artırdığı ifade edilebilmektedir. Aynı zamanda, bireylerin sağlık hizmeti kullanımında toplam faktör verimliliğini artırarak çıktıda artış yaratacağı da düşünülmektedir. Dolayısıyla yapılan araştırma, ekonomik büyümenin sağlık koşullarındaki iyileştirmelerde artış yaratarak sağlık durumunu olumlu yönde etkilediğini gösteren teorik ve ampirik literatüre katkı sağlamaktadır.

Ulaşılan sonuçlar doğrultusunda, ekonomik büyüme ile sağlık harcamalarının birbirinden bağımsız olmadığ1 görülmektedir. Bu kapsamda, karar vericiler açısından ekonomi ve sağlık politikalarının entegrasyonu için ekonomik büyümenin öneminin göz önüne alınması gerektiği salık verilmektedir. Bununla birlikte politika yapıcıların sağlık koşullarını geliştirerek, ülkenin beşeri sermayesinin üretkenliği ve ekonomik büyümesi üzerinde olumlu çıktılar yaratması önerilmektedir. Ayrıca, kamu sektörü tarafından finanse edilen sağlık yatırımlarının, kişi başına sağlık harcamaları üzerindeki getirilerinin ve verimliliğinin artırılmasına yönelik stratejilerin belirlenmesi gerekmektedir.

\section{Kaynakça}

Acemoglu, D. \& Johnson, S. (2007). Disease and development: The effect of life expectancy on economic growth. Journal of Political Economy, 115(6), 925-985.

Ak, R. (2012). The relationship between health expenditures and economic growth: Turkish case. International Journal of Business Management \& Economic Research, 3(1), 404-409.

Ay, A., Kızılkaya, O., ve Koçak, E. (2013). Sağlık göstergeleri ile ekonomik büyüme arasındaki ilişki: Türkiye örneği. Niğde Üniversitesi İ̈BF Dergisi, 6(1), 163-172.

Aydın, A., ve Bashimov, G. (2018). Tarım sektöründe uzmanlaşma ve dış ticaret: MINT ülkeleri üzerine bir inceleme. Alınteri Sosyal Bilimler Dergisi (ASOBİAD), 2(4), 261-282. doi: 10.30913/alinterisosbil.373574.

Baltagi, B. H. \& Moscone, F. (2010). Health care expenditure and income in the OECD reconsidered: Evidence from panel data. Discussion Paper Series, No. 4851, 1-22. 
Bhargava, A., Jamison, D. T., Lau, L. \& Murray, C. J. L. (2001). Modeling the effects of health on economic growth. Journal of Health Economics, 20(3), 423-440.

Bloom, D. E., Canning D. \& Sevilla, J. (2001). The effect of health on economic growth: Theory and evidence. NBER Working Paper, No. $8587,1-26$.

Bloom, D. E., Canning D. \& Sevilla, J. (2004). The effect of health on economic growth a production function approach. World Development, 32(1), 1-13.

Brenner, M. H. (2005). Commentary: Economic growth is the mortality rate decline in the 20th century-experience of the United States 1991-2000. International Journal of Epidemiology, 34(6), 1214-1221.

Breusch, T. S. \& Pagan, A. R. (1980). The review of economic studies. Econometrics Issue, 47(1), 239-253.

Chaabouni, S. \& Saidi, K. (2017). The dynamic links between carbon dioxide $\left(\mathrm{CO}_{2}\right)$ emissions, health spending and GDP growth: A case study for 51 countries. Environmental Research, 158, 137-144.

Chakraborty, S. (2004). Endogenous lifetime and economic growth. Journal of Economic Theory, 116(1), 119-137.

Cole, W. M. (2019). Wealth and health revisited: Economic growth and wellbeing in developing countries, 1970 to 2015. Social Science Research, 77, 45-67.

Cutler D. M., Deaton, A. S. \& Lleras-Muney, A. (2006). The determinants of mortality. NBER Working Paper Series No. 11963,1 49. http://www.nber.org/papers/w11963 adresinden 18 Ağustos 2019 tarihinde erişilmiştir.

Çağlayan Akay, E. (2015). Dinamik panel veri modelleri. S. Güriş (Ed.), Stata ile panel veri modelleri (ss. 81-104). İstanbul: Der Yayınları: 454.

Çetin, M., ve Ecevit, E. (2010). Sağlık harcamalarının ekonomik büyüme üzerindeki etkisi: OECD ülkeleri üzerine bir panel regresyon analizi. Doğuş Üniversitesi Dergisi, 11(2), 166-182.

Doğan, İ. (2016). Verimlilik, ekonomik büyüme ve sağlık ilişkisi: Türkiye için doğrusal olmayan nedensellik testi. Ekonomi ve Yönetim Araştırmaları Dergisi, 2(2), 21-48.

Dünya Bankas1, (2019, Ağustos 26). https://databank.worldbank.org/indicator/NY.GDP.MKTP.KD.ZG/1ff4a498/Popular-Indicators\# adresinden 26 Ağustos 2019 tarihinde erişilmiştir.

Dünya Sağlık Örgütü, (2019, Ağustos 19). https://www.who.int/about/who-we-are/constitution adresinden 19 Ağustos 2019 tarihinde erişilmiştir.

Gallardo-Albarrán D. (2018). Health and economic development since 1900. Economics and Human Biology, 31, 228-237.

Green, W. H. (2010). Models for panel data. http://people.stern.nyu.edu/wgreene/Lugano2013/Greene-Chapter-11.pdf adresinden 7 Mayıs 2017 tarihinde erişilmiştir.

Gujarati, D. N. (2004). Basic econometrics. USA: The McGraw-Hill Companies.

Güriş, S. (2015). Panel veri ve panel veri modelleri. S. Güriş (Ed.), Stata ile panel veri modelleri (ss. 1-38). İstanbul: Der Yayınları: 454.

IMF, (2019, Ağustos 31). https://www.imf.org/external/pubs/ft/weo/2019/01/weodata/download.aspx. adresinden 31 Ağustos 2019 tarihinde erişilmiştir.

Kyriopoulos, I., Nikoloski, Z. \& Mossialos, E. (2019). Does economic recession impact newborn health? Evidence from Greece. Social Science \& Medicine, 237, 112451.

Maisonneuve, C. \& Oliveira Martins, J. (2013). A projection method for public health and long-term care expenditures. $O E C D$ Economics Department Working Papers, No. 1048, OECD Publishing. http://dx.doi.org/10.1787/5k44v53w5w47-en.

Malik G. (2011). An examination of the relationship between economic growth and health. PWC, 1-19. https://www.researchgate.net/publication/215902111 adresinden 6 Aralık 2017 tarihinde erişilmiştir.

Mehrara, M., Fazaeli, A. A., Fazaeli, A. A. \& Fazaeli, A. R. (2012). The relationship between health expenditures and economic growth in Middle East \& North Africa (MENA) countries. Int. J. Buss. Mgt. Eco. Res, 3(1), 425-428.

Novignon, J., Olakojo, S. A. \& Nonvignon, J. (2012). The effects of public and private health care expenditure on health status in subSaharan Africa: New evidence from panel data analysis. Health Economic Review, 2(22), 1-8.

Odubunmi, A. S., Saka, J. O. \& Oke, D. M. (2012). Testing the cointegrating relationship between health care expenditure and economic growth in Nigeria. International Journal of Economics and Finance, 4(11), 99-107. 
Pritchett, L. \& Summers, L. H. (1996). Wealthier is healthier. Journal of Human Resources, 31(4), 841-868.

Rad, E. H., Vahedi, S., Teimourizad, A., Esmaeilzadeh, F., Hadian, M. \& Pour, A. T. (2013). Comparison of the effects of public and private health expenditures on the health status: A panel data analysis in Eastern Mediterranean countries. International Journal of Health Policy and Management, 1(2), 163-167.

Rezaei, S., Fallah, R., Karyani, A.K., Daroudi, R., Zandiyan, H. \& Hajizadeh, M. (2016). Determinants of healthcare expenditures in Iran: Evidence from a time series analysis. Medical Journal of the Islamic Republic of Iran, 30, 313.

Samadi, A. \& Rad, E. H. (2013). Determinants of healthcare expenditure in Economic Cooperation Organization (ECO) Countries: Evidence from panel cointegration tests. International Journal of Health Policy and Management, 1(1), 63-68.

Selim, S., Uysal, D., ve Eryiğit P. (2014). Türkiye'de sağlık harcamalarının ekonomik büyüme üzerindeki etkisinin ekonometrik analizi. Niğde Üniversitesi İktisadi ve İdari Bilimler Fakültesi Dergisi, 7(4), 13-24.

Spiteri, J. \& von Brockdorff, P. (2019). Economic development and health outcomes: Evidence from cardiovascular disease mortality in Europe. Social Science \& Medicine, 224, 37-44.

Taban, S. (2006). Türkiye'de sağlı ve ekonomik büyüme arasındaki nedensellik ilişkisi. Sosyoekonomi, 4(4), 31-46.

Tıraşoğlu, M., ve Yıldırım, B. (2012). Yapısal kırılma durumunda sağlık harcamaları ve ekonomik büyüme ilişkisi: Türkiye üzerine bir uygulama. Electronic Journal of Vocational Colleges, 2(2), 111-117.

Wang, Q. \& Granados, J. A. T. (2019). Economic growth and mental health in 21st century China. Social Science \& Medicine, 220 , 387-395.

Yumuşak, İ. G., ve Yıldırım, D. Ç. (2009). Sağlık harcamaları iktisadi büyüme ilişkisi üzerine ekonometrik bir inceleme. The Journal of Knowledge Economy \& Knowledge Management, 4(1), 57-70.

Zhao, Y,. Li, K. \& Zhang, L. (2019). A meta-analysis of online health adoption and the moderating effect of economic development level. International Journal of Medical Informatics, 127, 68-79. 